\title{
EXPLORING AGRICULTURAL OPPORTUNITIES IN THE CLAY BELT OF ONTARIO, CANADA
}

\author{
DANIELLE ROBINSON, WAYNE CALDWELL \& SARA EPP \\ School of Environmental Design and Rural Development, University of Guelph, Canada
}

\begin{abstract}
There are various clay belts within the Canadian Shield which represent the beds of Pleistocene lakes. The soils and terrain are more suitable to agricultural use than the surrounding shield. The best known of these clay belts lies along the 49th parallel for over $800 \mathrm{~km}$ in the Canadian provinces of Ontario and Quebec. The Clay Belt area in northeastern Ontario consists of 10.2 million acres of land, 35\% of which is covered in coniferous forest and $28 \%$ in mixed forest. The Clay Belt of northeastern Ontario has experienced agricultural growth followed by dramatic decline marked by occasional small reversals; agricultural land in the area peaked in 1951 since which time it has steadily declined although there are recent indications of renewed interest in the abundance of viable agricultural land in the region with the provincial government and agricultural groups in Ontario actively promoting related opportunities. Evolutionary economic geography's emphasis on the significance of history and geography in understanding the development of spatial economies can be applied to the region to better understand how the processes of path creation and path dependence have interacted to shape the geographies of agricultural development in the region. This region has the potential to contribute significantly to agricultural development, food production and in turn benefit local rural economies. The trajectory of agricultural development, however, tells a story of economic, social and environmental barriers that affect sustainability and related environmental impact. This paper will consider the opportunities for agricultural development, while recognizing the need for policy that is sensitive to community needs. Keywords: food systems, food policies, rural development, evolutionary economic geography, Clay Belt.
\end{abstract}

\section{INTRODUCTION}

There are various clay belts within the Canadian Shield which represent the beds of Pleistocene lakes. The soils and terrain of which are more suitable to agricultural use than the surrounding shield. The best-known clay belt lies along the 49th parallel for over $800 \mathrm{~km}$ in the Canadian provinces of Ontario and Quebec [1]. Formally referred to as the "Clay Belt" in northeastern Ontario it consists of 10.2 million acres of land, $35 \%$ of which is covered in coniferous forest and $28 \%$ in mixed forest. Potentially fertile glaciolacustrine and morainal calcareous clays and silts make up $66 \%$ of the area [2], [3]. Much of northeastern Ontario is located within the Ontario Shield Ecozone [4]. The climate in this region is typified by long, cold winters and short, warm summers, with the mean annual temperature ranging from $-0.5-2.5^{\circ} \mathrm{C}$ and the annual mean precipitation ranging from 652 to $1,029 \mathrm{~mm}$ [5]. Fig. 1 shows the Canadian Clay Belt, with communities one through five being in the Ontario Clay Belt.

The Clay Belt is of special interest to geographers because social and cultural differences in Ontario and Quebec have caused different population and distribution patterns [6]. From initial land surveying, to support programs, to spatial patterns of decline, agricultural settlement evolved differently on either side of the provincial border. Ontario's settlement approach has been considered laissez-faire while Quebec's has been considered more paternal [1], [6], [7]. These differences become obvious when the level of agricultural development is compared across provinces. The rural agricultural economy in Quebec 


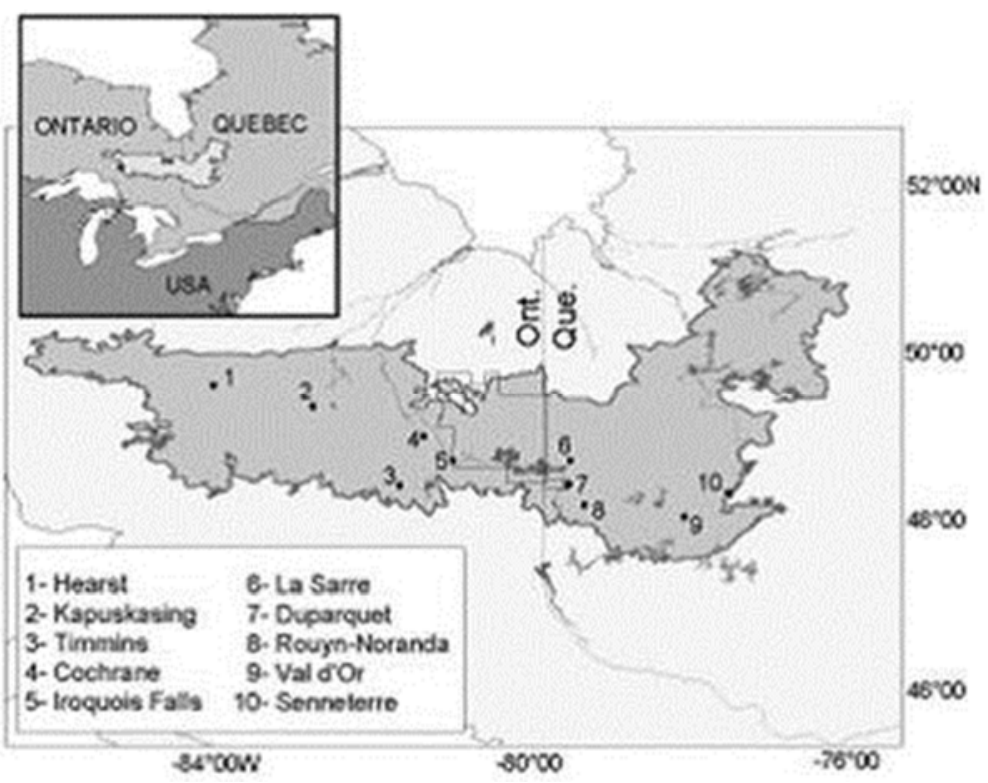

Figure 1: The Clay Belt [3].

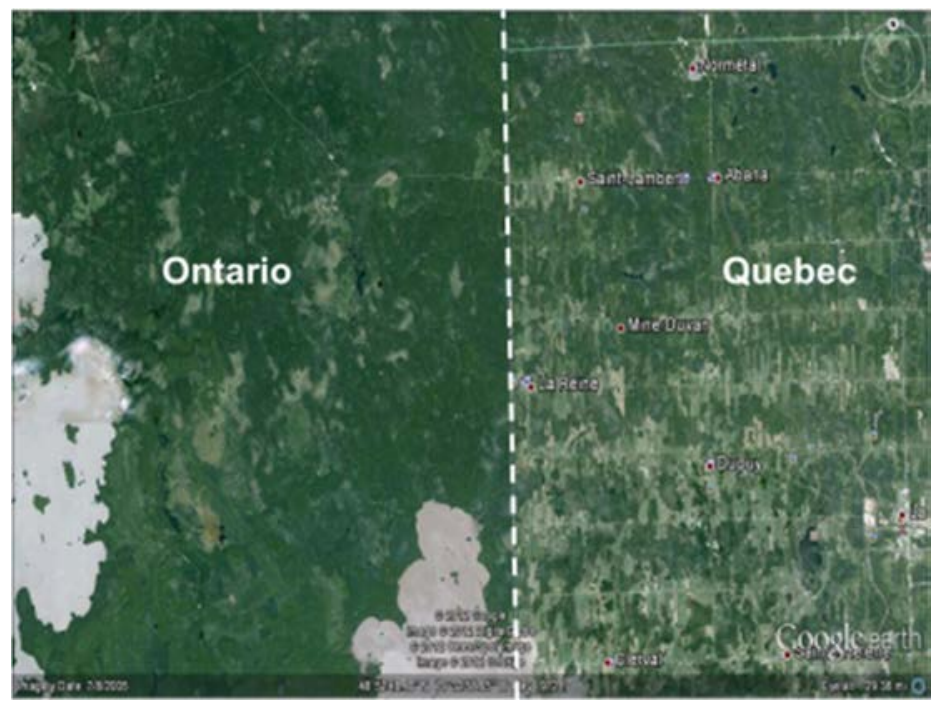

Figure 2: Development differences in the Clay Belt [3].

appears more developed than that of northeastern Ontario. Fig. 2 shows the agricultural development differences between northeastern Ontario (west or left of border) and northwestern Quebec (right or east of the line).

The Clay Belt of northeastern Ontario has experienced agricultural growth followed by dramatic decline marked by occasional small reversals; agricultural land in the area peaked 
in 1951 since which time it has steadily declined [8]. However, there are recent indications of renewed interest in the abundance of viable agricultural land in the region [9]. Evolutionary economic geography's emphasis on the significance of history and geography in understanding the development of spatial economies can be applied to the region to better understand how the processes of path creation and path dependence have interacted to shape the geographies of agricultural development in the region.

Evolutionary economic geography is concerned with how the landscape of economic production, distribution and consumption change over time [10]. Path dependence theory, one of evolutionary economic geography's major theoretical frameworks, is a type of place dependence in which past events and outcomes shape local or regional outcomes in the present and future [11].

Evolutionary economic geography has usually focused on urban regions and industries such as manufacturing and services, but it has the potential to meaningfully contribute to analyses of rural economic change [12]. Typically, rural change analysis tends to take a shortterm view of typically only one or two decades [12]. However, making sense of the present requires a much longer view since social, cultural, economic and environmental conditions frequently have earlier sources, therefore this analysis uses academic literature and industry and government reports to consider agricultural development in the Clay Belt region of Northeastern Ontario from the early 20th century to the present.

This research is part of "Understanding the Barriers to Livestock Production in the Clay Belt: An Economic, Social and Environmental Analysis", an InnovaNor/Université de Hearst and the University of Guelph participatory action research project supported by funding from the Ontario Ministry of Agriculture, Food and Rural Affairs' (OMAFRA) New Directions Research Program and part of the Northern Livestock Pilot Project focussed on an area of the Clay Belt along Highway 11 between Hearst and Cochrane in northeastern Ontario [9]. "Understanding the Barriers to Livestock Production in the Clay Belt: An Economic, Social and Environmental Analysis" aims to identify the barriers that prevent individuals and communities from engaging in livestock production in northern Ontario and proposes concrete solutions, both on the institutional/political level and on the individual level, in order to reduce or eliminate these barriers. Since regional contexts offer public policy opportunities and constraints, this research takes the Ontario Clay Belt's agricultural history as a starting point to identifying environmentally, economically and socially sustainable regional opportunities.

\section{AGRICULTURE IN THE ONTARIO CLAY BELT}

The Clay Belt was opened for agricultural settlement in about 1910. McDermott [6], Kent [7], and Vanderhill [1] place early 20th century agricultural expansion into the Clay Belt within the context of a colonial period in Canadian history when it was logical to assume that high demand for agricultural land would continue. Encouraging colonization in outlying regions was seen as a way to meet the needs of a growing population. Agricultural development was closely linked to transportation with early agricultural settlements forming along railway routes [6].

Settlement was encouraged by government and land was relatively inexpensive during the first half of the 20th century. Specific initiatives to attract farmers included the Soldier-Sailor Settlement Agreement which granted World War One veterans 160 acres of land and the Relief Land Settlement Scheme of the 1930s which granted $\$ 600$ for transportation, land purchase, building and equipment [7]. Northern Ontario Crown land, land that is owned and managed by the provincial or federal governments, for farming was available to settlers for 50 cents an acre until the 1960s [7]. 
Despite land affordability and government encouragement, agricultural land abandonment has been a major problem associated with the settlement of the Ontario Clay Belt [6]. For example, hundreds of settlers participated in the Relief Land Settlement Plan in 1932 and 1933, but the vast majority eventually abandoned farming [1], [6], [7]. In 1941, there were 14,000 people living on 3,060 farms, but by 1976, 1,104 people were living on 285 farms [1]. By 2006, improved lands had declined to about 35,000 acres [6]. The decrease in farm population and number of farms seen in the Ontario Clay Belt echoes the larger pattern across North America during the same time period; however, unlike other areas that experienced a decrease in farm population and number of farms, abandoned land in the Clay Belt was not absorbed into existing farms. In the Ontario Clay Belt's case, farm land was more frequently abandoned completely rather than consolidated into fewer larger farms [6].

The Clay Belt is still described as having an abundance of viable agricultural land; there are 4.4 million acres of high quality soil, identified as class 2,3 and 4 soils on a scale of 1 to 7, within Ontario's portion [2], [13]. Much of this land continues to be underutilized, with fallow fields and in some instances, decaying infrastructure [3], [13]. Drainage and climate have limited agricultural productivity in the Clay Belt, but systematic tile drainage, long-term climate warming and the development of new crop varieties and agronomic techniques have mitigated these limitations [7]. Obstacles to agriculture in the region "tend to lie in socioeconomic factors which suggests that agriculture could return and expand given the appropriate socio-economic conditions" [13, p. 9] therefore, this analysis focuses on economic and social barriers.

\subsection{Economic barriers}

\subsubsection{Market access}

Lack of a substantial local market and transportation that takes longer, costs more and is more complicated are central challenges to agri-business profitability in rural and remote areas [14]. In the 1960s, there was a small local market for agriculture products and there was some optimism that mining might stabilize agriculture since mines use local produce [7]. However, by 1988 it was clear that forest and mining communities would not provide a stable local market for mixed agriculture in the Clay Belt [1]. The flow of agricultural products and services typically moved from south to north and local farm production was not considered critical as the Clay Belt was predominately serviced from out-of-region [1]. Transportation costs for transporting Clay Belt agricultural products to outside markets were too high to be competitive and since there was only limited food processing in the area, raw products had to be shipped out and processed foods shipped in which incurred further costs [7].

Local markets continue to be limited and transportation challenges continue to negatively impact area farmers' access to service, supplies and markets. Local infrastructure and equipment are lacking, making rural communities and smaller growers dependent upon highly centralized infrastructure for food production. The logistics and cost of trucking up special orders or small quantities can be prohibitive. Furthermore, distribution costs are higher as agri-food products must travel further to reach their market [14], [15].

\subsubsection{Labour}

Competition for labour primarily from more lucrative employment options in mining and forestry has been an issue in the region for more than 50 years [6], [12]. Labour challenges have applied to both the landowner whose own labour was often spent in relatively attractive off-farm labour and to finding other workers for relatively unattractive on-farm labour. Mid20th century research found that farm labour shortages made farm maintenance challenging 
and resulted in many farms being in poor condition [7]. Run-down farms reduced the sense of a thriving landscape and reduced property values on neighbouring farms, so that abandonment triggered further abandonment [6]. Kent [7] correctly predicted that farm abandonment would continue and that any remaining settlers would derive very little of their income from farming but work at jobs elsewhere while continuing to live on their farm property.

Competition for labour with other, often higher paying industries continues to be a common barrier for farm businesses [13], [16]. It is currently compounded by the fact that overall Canada faces a demographic labour force challenge [17]. There are fewer young potential entrants to the workforce, compared to potential retirees from the workforce. Producers and processors have difficulty finding labour for their operations while the long hours and comparably lower wage can be difficult to justify for prospective farmers [13].

\subsubsection{Scale and support}

Farming in the Clay Belt has been historically dominated by small-scale farms [7]. Unfortunately, a rural perspective on policy that attends to the needs of small operators and the consequences of low population density and distance to density is often neglected in policy decision making [17]. In addition, small farms in the present-day Clay Belt often do not qualify for many support programs and supply-managed systems are often prohibitively expensive because policy is geared to larger producers [18]. This undermines the ability of smaller local growers to sustainably produce food for local consumers by favouring industrial, large-scale food production businesses. For example, the federal government's Agri-Competitiveness funding stream disadvantages smaller scale operators because the regulations to promote farm safety are often inappropriate to smaller farms [19]. There is a common opinion among current Clay Belt area farmers that farmers on the Quebec side of the border have a competitive advantage because of more supportive provincial service and subsidies [13].

\subsection{Social barriers}

\subsubsection{Knowledge}

Successful farming in the region requires appropriate knowledge and skills related to agriculture in Clay Belt conditions. For many early settlers', their unfamiliarity with the conditions of the Clay Belt as well as the techniques of their newly adopted means of livelihood caused discouragement and ultimately abandonment [6], [7]. Limited knowledge continues to be seen as a barrier to agriculture in the region [16], [18]. These issues are exacerbated by limited succession planning which was already a concern by the mid-20th century [7] and continues to be a concern today [13], [18]. The average age of a farm operator in Northern Ontario is 55 [20] and many rural communities struggle to retain their youth [21], [22]. This suggests that many farm operations will be left unutilized as farmers age and the knowledge and wisdom built through a lifetime of farming experience will be lost.

\subsubsection{Community}

A variety of farming and non-farming residents are needed to create the population base required to sustain the services and amenities that support rural well-being. Between 1851 and 2011, the rural population in Canada dropped from $90 \%$ to $18.9 \%$ of the total population [23]. The significance of amenities and services in the Ontario Clay Belt was noted by McDermott [6] who observed the interconnections between depopulation and the hollowing out of local institutions and business in the mid-20th century. Further decline in Clay Belt 
amenities was observed by Vanderhill [1]. From health care, to schools, to shops, to churches, when services and amenities are limited, rural communities struggle to retain and attract residents which then further exacerbates the challenges of providing amenities and services. These patterns have continued in the region [16]. As a result of youth out-migration and population aging, rural communities experience the closure of businesses and a declining population base, resulting in low levels of social capital [24]-[26]. Agriculture cannot thrive in the Clay Belt without amenities and services that meet basic needs and bring residents together, enhance social cohesion and create a sense of belonging among residents [27].

\section{AGRICULTURAL PATH DEPENDENCIES}

Several aspects of path dependence emerge related to the role of the state in economic development, the types of agricultural opportunities considered, the persistence of negative perceptions and social and economic marginalization.

\subsection{Barriers should be removed}

The fact that barriers have tended to be considered socio-economic factors implies that agriculture can thrive in the Ontario Clay Belt given appropriate socio-economic conditions [13]. Vanderhill [1] characterizes farmers' struggle to remain on the land and government initiatives to sustain the agricultural economy as inertia factors. Although Kent frames barriers as indicators that a different strategic direction is required and goes so far as to float the possibility that farmland in marginal agricultural regions "should go back to forest and water conservation uses and those attempting to live on them resettled in more rewarding surroundings" [7, p. 126], government and industry efforts to make Clay Belt agriculture economically, socially and environmentally viable have occurred to various degrees throughout the Clay Belt's agricultural history. McDermott [6] makes the economic costs and political dynamics involved in removing barriers clear in his analysis that "the government concerned must decide whether the advance of the frontier is desirable and whether it is willing to pay the price to achieve its goal." Whether and how these socialeconomic barriers might be removed and conditions more conducive to agriculture created are political questions related to the state's role in the provision of rural service and infrastructure.

\subsection{Livestock}

Livestock has been identified as a focus area for agricultural development in the region since at least the 1960s. Kent [7] suggests cow-calf operations as a form of agriculture that may be feasible in the clay belt and indicates that there had been many suggestions along those lines. As of 1976, there was a meaningful increase in the number of beef cattle in the Clay Belt [1]. In fact, the acreage of improved land in the Ontario Clay Belt increased by $8 \%$ between 1971 and 1981 reflecting a trend towards beef production. A shift in the work at the Agricultural Canada Experiment Station at Kapuskasing from field crops to a focus on the care and feeding of livestock was noted in 1988 [1].

The region is currently identified as suitable for forage production because the land is capable of supporting large herds of ruminant animals [2]. The increasing popularity for niche markets such as grass-fed, organic, or locally produced food and the area's ability to produce quality hay and pastures for grass-fed beef production are seen as creating opportunities for agriculture in the Clay Belt [16]. 
Previous paths that have emphasized the opportunities in livestock production did not include considerations of sustainable diets that have now become culturally, socially and environmentally significant. Proponents of plant-rich diets seek faster and further reductions in greenhouse gas emissions and propose that usual emissions could be reduced by as much as $70 \%$ through adopting a vegan diet and $63 \%$ for a vegetarian diet [28]. These considerations seem particularly important given Canada Food Guide's new emphasis on plant-based proteins [29]. Historical analysis did not include global warming considerations, but for both ethical and pragmatic reasons the environmental impact of livestock production needs to be critically considered, especially given that the production of animal products contributes significantly to human produced greenhouse gas emissions [30]. Although increased meat consumption presents a business opportunity, the environmental effects of increased production could exceed planetary boundaries unless it is accompanied by technological changes and dedicated mitigation [31]. Whether global warming will be a large enough external threat to transform development paths [9] remains to be seen.

\subsection{Persistent negative perceptions}

Negative perceptions are another persistent theme which intersects economic, social and environmental barriers. The Clay Belt region is commonly identified not for its agricultural potential, but rather as a region based on mining and forestry. Residents generally describe their own communities as being based on the mining and forestry sectors with little regard to agriculture, which creates a regional culture that seems to reinforce the expectation of a marginal agricultural sector [13]. Path dependence on mining and forestry may have lockedin the region to those industries at the expense of agricultural opportunities. In addition, federal and provincial governments are often perceived as being indifferent to Northern agriculture [16]. Regardless of whether governments are actually indifferent to issues affecting farmers in the Clay Belt, the perception of indifference is enough to act as a barrier. Similarly, the perception of limited opportunities for rural youth is a barrier regardless of how limited actual opportunities happen to be [32], [33]. Finally, many producers describe a limited market for local production regardless of the fact that farmers who have oriented their operations towards local markets have succeeded. These kinds of negative perceptions may threaten the expansion of local production and consumption in the region [16].

\subsection{Marginalization}

Certain perspectives on agricultural opportunities in the Ontario Clay Belt have been marginalized. Indigenous people, women, and visible minorities are largely absent from the literature. Indigenous people are not typically mentioned in early descriptions of the Clay Belt; the land is characterized as empty [7]. Systemic racism creates obstacles for Indigenous and minority participation in agriculture [15]. Additionally, despite evidence that Canadian farm women contribute significant labour and capital, the significant influence women have in family decisions to farm in the North is underappreciated in analysis [34], [35].

\section{OPPORTUNITIES}

\subsection{Re-localizing}

Distance to large markets continues to be a major obstacle to profitability, but there is renewed interest in the potential of local markets given that the strong trend in recent years towards the consumption of fresh food products near production sites is expanding the 
potential for market gardening and livestock production [36]. Fresh and affordable food products are frequently lacking in Indigenous and remote communities in Northeast Ontario. There are opportunities to improve the linkages between farmers looking for local markets and Indigenous and remote communities [13], [16]. Northern Ontario's Agri-Food Strategy identified increasing Northern consumption of produce in the North as one of its key strategic priorities [37].

\subsection{Affordable agricultural land}

Land access is frequently identified as the most significant barrier to new farmers in other regions [38]-[40], but land access has been an attraction instead of a barrier in the Ontario Clay Belt [1]. The Clay Belt situation continues to be unique and advantageous since land remains comparatively affordable. The challenge will be ensuring that agricultural land remains affordable given the dramatic increases in Southern Ontario [40].

\subsection{Education for retention}

The most significant economic and social barriers to agricultural development in the region relate to farmer retention. Education and training are key to improving retention. Existing farmers need regionally-based extension services on topics such as low-input agriculture and adaptation to climate change [17] so they can continue to farm successfully in changing conditions. Farmer-to-farmer mentoring, and the transfer of knowledge and skills is critical for the next generation. More opportunities for learning within the agricultural community through the use of peer-learning, extension, and outreach are also required [13]. There is also a risk of losing prospective new farmers at the outset if there are not affordable, accessible ways for those from non-farm backgrounds to explore a career in agriculture, therefore, new farmer training programs are needed in urban, as well as rural communities, to engage potential new farmers [17] and provide the education and support required for on-going success.

\subsection{Diversity}

Identifying opportunities and removing barriers to agriculture in the Ontario Clay Belt requires continued examination of the multiplicities within farming because treating farmers as one homogeneous group over-emphasizes the role of territorial institutions [8]. This includes the experience of Indigenous people, women, visible minorities and other groups who have been historically marginalized. Diverse perspectives may emphasize different facets of the challenges to farming in the Ontario Clay Belt. For example, from the perspective of the well-being of children, access to community services like education, recreation and health care become a top priority. Reducing economic barriers without attention to social barriers will not retain farming families. Likewise, if economic barriers are addressed, but new farmers experience prejudice racism and feel unwelcome, it is unlikely they will persist. Further investigation of diverse farmers who continue to successfully farm in this geographically, socially and economically challenging area can provide useful insights as demonstrated in recent research assessing resilience in Northern Ontario agriculture using the case of Old Order Mennonite Communities [41]. 


\subsection{Comparative research}

Although regional development disparities remain in remote areas of Quebec, various economic indicators show that overall rural Quebecers' incomes, unemployment levels and labour market participation levels are getting closer to urban Quebecers [42]. Likely a variety of interconnected social, economic and political conditions support this situation, therefore, a holistic examination of how the Clay Belt region in Quebec attracts and retains farmers would be worthwhile to help identify potential best practices. Reflecting on the existing patterns related to the role of the state in rural economic development, the types of agricultural opportunities considered, the persistent perceptions and the voices and experiences included or excluded will help the Ontario Clay Belt identify and capitalize on agricultural opportunities.

\section{CONCLUSION}

Evolutionary economic geography has considerable value in interpreting processes of rural development. Examining historical analysis of agriculture in the Clay Belt of Northern Ontario revealed how processes of path creation and path dependence have interacted to influence the current geographies of agricultural development. For more than 100 years, the Clay Belt of Northern Ontario has been identified as having great potential to expand its agrifood economy because of its vast, affordable land base. That potential has attracted farmers to the region but retaining those farmers in active agriculture has been challenging. Historically, climate and drainage have presented significant barriers to agriculture in the region, but the most significant barriers have always been economic and social factors: lack of local markets, higher transportation costs, competition for labour, scale-policy mismatches, and most importantly social factors relating to human and social capital in rural communities. Examining agriculture in Ontario's Clay Belt using an evolutionary economic geography lens revealed that past circumstances affect the opportunities and approaches considered in the region.

\section{REFERENCES}

[1] Vanderhill, B.G., Agriculture's struggle for survival in the great clay belt of Ontario and Quebec. American Review of Canadian Studies, 18(4), pp. 455-464, 1988.

[2] Ontario Ministry of Agriculture, Food and Rural Affairs (OMAFRA), Northern Ontario region at a glance. www.omafra.gov.on.ca/english/stats/county/ northern_ontario.htm\%0A4. Accessed on: 21 Sep. 2018.

[3] Ontario Ministry of Agriculture Food and Rural Affairs (OMAFRA), Northern Ontario agriculture facts and figures in brief. www.omafra.gov.on.ca/english/livestock/beef/ news/info_vbn0713a4.htm. Accessed on: 21 Sep. 2018.

[4] Northern Ontario Heritage Fund Corporation (NOHFC), About us. https://nohfc.ca/en/ pages/about-us. Accessed on: 21 Sep. 2018.

[5] Lalonde, R., Gleeson, J., Gray, P.A., Douglas, A., Blakemore, C. \& Ferguson, L., CCRR-24 responding to climate change through partnership climate change vulnerability assessment and adaptation options for Ontario's Clay Belt : A case study, 2012.

[6] McDermott, G., Frontier of settlement in the Great Clay Belt, Ontario and Quebec. Annals of the Association of American Geographers, 51(3), pp. 261-273, 1961.

[7] Kent, J., Agriculture in the Clay Belt of northern Ontario. Canadian Geographer, 10(2), pp. 117-126, 1966. 
[8] Manseau, R., Northern Claybelt agri-network phase i report: Land inventory and soil classification update and analysis, Timmins: Ontario, 2008.

[9] Ontario Ministry of Agriculture Food and Rural Affairs (OMAFRA), Northern Ontario agri-food strategy strengthening the agriculture, aquaculture and food sector, 2017. www.omafra.gov.on.ca/english/northernagrifood/noas.htm. Accessed on: 14 Jan. 2020.

[10] Boschma, R. \& Martin, R., The aims and scope of evolutionary economic geography. Papers in Evolutionary Economic Geography (PEEG), 1001, Utrecht University: Department of Human Geography and Spatial Planning, Group Economic Geography, pp. 3-39, 2010.

[11] Tonts, M., Plummer, P. \& Argent, N., Path dependence, resilience and the evolution of new rural economies: Perspectives from rural Western Australia. Journal of Rural Studies, 36, pp. 362-375, 2014.

[12] Tonts, M., Argent, N. \& Plummer, P., Evolutionary perspectives on Rural Australia. Geographical Research, 50(3), pp. 291-303, 2012.

[13] Caldwell, W. \& Marr, E., Strategic Directions for Agricultural Development in Northeastern Ontario: Northeast Community Network (NeCN) Agriculture Study Report 2, Guelph, 2011.

[14] Caldwell, W., Howes, K. \& Epp, S., Facilitating the Agricultural and Local Food Sector in Northern Ontario: A Municipal Toolkit, Guelph, 2018.

[15] Food Secure Canada, Discussion paper: Food sovereignty in rural and remote communities. https://foodsecurecanada.org/sites/foodsecurecanada.org/files/DP2 Food_Sovereignty_in_Rural_and_Remote_Communities.pdf. Accessed on: 24 Sep. 2018 .

[16] Caldwell, W. \& Marr, E., Current and Future Opportunities for Agricultural Development in Northeast Ontario: A Regional Development Perspective - Northeast Community Network (NeCN) Agriculture Study: Report 1, Guelph, 2011. www.ruralplanninganddevelopment.ca/casestudy/NeCN\%20Agriculture $\% 20$ Study $\%$ 20-\%20Report\%201\%20-\%2018\%20November\%202011.pdf. Accessed on: 15 Jan. 2020.

[17] Lauzon, A., Bollman, R. \& Ashton B., Introduction. The State of Rural Canada, Canadian Rural Revitalization Foundation (CRRF), 2015. http://sorc.crrf.ca/. Accessed on: 24 Sep. 2018.

[18] FarmStart Ontario, National farm renewal initiative: Policy recommendations. 2016. https://foodsecurecanada.org/sites/foodsecurecanada.org/files/national_farm_renewal init_oct_20161.pdf. Accessed on: 24 Sep. 2018.

[19] Martorell, H., Canadian policy landscape for local, sustainable food systems, Food Secure Canada, 2017. https://fledgeresearch.ca/wp-content/uploads/2017/08/ discussion_paper_canadian_policy_landscape_for_local_sustainable_food_systems_ final2017_.pdf. Accessed on: 15 May 2019.

[20] Statistics Canada, 2016 Census of Agriculture. www.statcan.gc.ca/eng/ca2016. Accessed on: 28 May 2018.

[21] Alston, M., Who is down on the farm? Social aspects of Australian agriculture in the 21st century. Agriculture and Human Values, 21(1), pp. 37-46, 2004.

[22] Jamieson, L., Migration, place and class: Youth in a rural area. The Sociological Review, 48(2), pp. 203-223, 2000.

[23] Statistics Canada, 2016 Census: 150 years of urbanization in Canada, 2017. www.statcan.gc.ca/eng/sc /video/2016census_150yearsurbanization. Accessed on: 28 May 2018. 
[24] Ball, A.L. \& Wiley, A., The aspirations of farm parents and pre-adolescent children for generational succession of the family farm. Journal of Agricultural Education, 46(2), pp. 36-46, 2005.

[25] Dale, A. \& Onyx, J. (eds), A Dynamic Balance: Social Capital and Sustainable Community Development, UBC Press: Vancouver, 2010.

[26] Stain, H.J., Kelly, B., Lewin, T.J., Higginbotham, N., Beard, J.R. \& Hourihan, F., Social networks and mental health among a farming population. Social Psychiatry and Psychiatric Epidemiology, 43(10), 2008.

[27] Oncescu, J. \& Giles, A., A rural school's closure: Impacts on volunteers' gender roles. Rural Sociology, 23(1), pp. 2-19, 2013.

[28] Hawken, P. (ed.), Drawdown: The Most Comprehensive Plan Ever Proposed to Reverse Global Warming, Penguin, 2017.

[29] Hui, A., The new Canada's Food Guide explained: Goodbye four food groups and serving sizes, hello hydration. Globe and Mail, 22 Jan. 2019.

www.theglobeandmail.com/canada/article-new-canadas-food-guide-explained/.

Accessed on: 23 Jan. 2019.

[30] Gerber, P.J. et al., Tackling climate change through livestock - A global assessment of emissions and mitigation opportunities. Food and Agriculture Organization of the United Nations (FAO), 2013. www.fao.org/3/a-i3437e.pdf. Accessed on: 15 Jan. 2020.

[31] Springmann, M. et al., Options for keeping the food system within environmental limits. Nature 562(7728), pp. 519-525, 2018.

[32] Corbett, M. \& Forsey, M., Rural youth out-migration and education: Challenges to aspirations discourse in mobile modernity. Discourse: Studies in the Cultural Politics of Education, 38(3), pp. 429-444, 2017.

[33] Davies, A., Declining youth in-migration in rural Western Australia: The role of perceptions of rural employment and lifestyle opportunities. Geographical Research, 46(2), pp. 162-171, 2008.

[34] Martz, D.J.F., Canadian farm women and their families restructuring work and decision making. Doctoral thesis, University of Saskatchewan, 2006.

[35] Roppel, C., Martz, D.J.F. \& Desmarais, A.A., Farm women and Canadian agricultural policy, 2006. www.cwhn.ca/en/node/28233. Accessed on: 23 Apr. 2018.

[36] Martinez, S., Local Food Systems; Concepts, Impacts, and Issues, Diane Publishing, 2010.

[37] Ontario Ministry of Agriculture Food and Rural Affairs (OMAFRA), The growth plan for northern Ontario: An overview. www.omafra.gov.on.ca/english/northernagrifood/ index.htm. Accessed on: 21 Sep. 2018.

[38] Food Secure Canada, Policy atlas local and sustainable food systems, 2017. https://foodsecurecanada.org/sites/foodsecurecanada.org/files/files/policy_atlas_local _sustainable_food_systems_2017_.pdf. Accessed on: 22 May 2019.

[39] Serkoukou, B.M., New farmer programs: Support programs for new entrants to farming in the European Union and Quebec, 2014. https://foodsecurecanada.org/sites/ foodsecurecanada.org/files/nfiresearch_finalreport_apr14_0.pdf. Accessed on: 23 Sep. 2018.

[40] Miller, S., Places to farm: Alternative practices and policies for Ontario's changing agricultural landscape, 2013.

[41] Epp, S., Assessing resilience in agriculture: A case study of Old Order Mennonite communities in Northern Ontario. Doctoral dissertation, University of Guelph, 2018. 
156 Environmental Impact V

[42] Guimond, L. \& Jean, B., Québec, in State of Rural Canada, Canadian Rural Revitalization Foundation (CRRF), 2015. http://sorc.crrf.ca/quebec/. Accessed on: 15 Jan. 2020. 